there are indexes of authors and titles. Mr. Ordway's claim that he has listed "all significant Englishlanguage titles since . . 1931" is very nearly true, and his summaries are fair and informative. Altogether, this is a most useful reference book, both for librarians and for working scientists.

\section{The European Common Market}

A THIRD revised edition of the bibliography compiled by J. E. Wild on The European Common Market and the European Free Trade Association has been issued as Special Subject List No. 35 (Pp. 64. London: The Library Association, 1962. 9s.; L.A. Members, 6s. 9d.). It is in two parts, the first covering books, pamphlets and reports, and the second periodical articles. There is also a short list of bibliographies, reading lists, etc. There are some 750 entries arranged alphabetically by authors, and also a name and subject index. The entries are selected to cover as many aspects of European economic integration as possible, including, for example, scientific manpower, and giving prominence to such controversial matters as agriculture, the Commonwealth problem, competition and sovereignty.

\section{The International Commission on Zoological Nomenclature}

Notice is hereby given of the possible use by the International Commission on Zoological Nomenclature of its plenary powers in connexion with the following cases, full details of which will be found in the Bulletin of Zoological Nomenclature (19, Part 4, published on July 16, 1962): (1) Validation and interpretation of the generic name Endothyra Phillips, [1846] (Foraminifora). Z.N.(S.) 768 . (2) Designation of a type-species for Boa Linnaeus, 1758 (Reptilia). Z.N.(S.) 1188. (3) Validation and interpretation of the specific name Culex aegypti Linnaeus, 1762 (Insecta, Diptera). Z.N.(S.) 1216. (4) Suppression of the specific name Pachyodon nucleus Brown, 1843 (Pelecypoda). Z.N.(S.) 1470. (5) Validation of the emendations Dorhynchus (of Dorynchus Thomson, 1873), and stirhynchus (of stirynchus (Axius) Leach, 1815); designation of a type-species for Callinectes Stimpson, 1860 ; validation of the family name Potamonidae Ortmann, 1896; validation of the specific names Callinectes sapidus Rathbun, 1896, and Goneplax sexdentatus Risso, 1827 (Crustacea, Decapoda). Z.N.(S.) 1499. (6) Validation of Mörch, 1853-1858, Catalogus Conchyliorum and designation of a type-species for Pseudamussium Mörch, 1853 (Pelecypoda). Z.N.(S.) 1501. Any zoologist who wishes to comment on any of the above cases should do so in writing to the Secretary, International Commission on Zoological Nomenclature, c/o British Museum (Natural History), Cromwell Road, London, S.W.7, before January 16, 1963.

The Institute of Physics and the Physical Society

Aт the second annual general moeting of the amalgamated Institute of Physics and the Physical Society, held in London on July 10, the following were elected to office: President, Sir Alan Wilson; Vice-President, Prof. B. H. Flowers; Honorary Treasurer, Dr. J. Taylor; Honorary Secretary, Dr. C. G. Wynne. The three new Ordinary Members of the Council elected were: Dr. D. H. Follett, Prof. M. H. L. Pryce and Prof. A. M. Taylor. Prof. P. M. S. Blackett, Sir John Cockeroft, Prof. W. E. Lamb, jun., and Prof. C. F. Powell were elected Honorary
Fellows in recognition of their eminent work and valuable contributions to knowledge in the field of physics.

\section{Natural History Certificate Course}

The University of London awards a certificate of proficiency in natural history. This certificate is available to all persons interested in the study of living things in their natural habitats. The work involves a directed course of private reading at home, attendance at a practical course of four-weeks duration in the spring and summer, an approved plan of fieldwork suited to the student's locality to be written up in the form of an essay, and examinations. Students wishing to begin their directed course of reading can apply at any time before November 15 for registration with the view of attending next year's practical course which (subject to sufficient entries) will be held at suitable field centres for one week in April and for three weeks in August. The regulations and application form can be obtained from the Secretary, Natural History Certificate Course, Department of Extra-Mural Studies, University of London, Senate House, London, W.C.1.

Grants for Humanities and Social Sciences in Israel

THE Edmond James de Rothschild Memorial Group is offering several fellowships to enable leading authorities in the humanities and the social sciences to spend a period of six months to a year at the Technion-Israel Institute of Technology, Haifa. Candidates must be men of recognized academic standing at a university or other institution outside Israel, of sufficient calibre and experience to enable them to assist in the broadening of the basis of the humanities and the social sciences at the Technion. They will be expected to deliver a course of lectures in their field of specialization and generally stimulate (and receive stimulation from) the student body and faculty of the Institute. Each fellowshipholder will receive a grant of 7,000 dollars per year (or 3,500 dollars for six months), and tourist-class round-trip fare between his home country and Haifa. Technion will undertake to provide him with suitable housing for the duration of his stay. Application should be made in writing to the Registrar, TechnionIsrael Institute of Technology, P.O.B. 4910, Haifa, Israel, before September 1 for the academic year 1962-63, and February $I$ for the academic year $1963-64$.

\section{Symposium on Antarctic Biology}

A symposium on Antarctic Biology will be held in Paris during September 2-8. It is being organized by the Scientific Committee on Antarctic Research (S.C.A.R.) with the co-operation of the French Academy of Sciences at the Faculté de Médecine, 45 Rue des Saints-Pères, Paris. Its aims are to review progress in Antaretic biological research, to discuss the most profitable lines of future research, to integrate Antarctic work with biological research elsewhere, and to discuss the special problems involved in research in the Antarctic and Subantarctic, including international co-operation. The opening address will be given by Prof. P. P. Grassé, chairman of the Organizing Committee.

The following sessions will be held: the life sciences in the Antaretic; medical research; microbiology; biogeography and systematics-botany; biogeography and systematics-marine zoology; biogeography and systematics - terrestrial zoology; 